\title{
HUBUNGAN KONSUMSI TABLET FE DENGAN KADAR HB SAAT MENSTRUASI PADA REMAJA DI SMA NEGERI 1 LEBAKWANGI KECAMATAN LEBAKWANGI KABUPATEN KUNINGAN
}

\author{
Yona Septina \\ Sekolah Tinggi Ilmu Kesehatan Kuningan Garawangi \\ yonaseptina@stikku.ac.id
}

\begin{abstract}
Abstrak
Anemia merupakan salah satu masalah kesehatan di seluruh dunia. Remaja putri merupakan salah satu kelompok yang rawan terhadap defisiensi zat besi atau yang biasa disebut sebagai anemia. Tujuan dari penelitian ini adalah untuk mengetahui adanya hubungan konsumsi tablet $\mathrm{Fe}$ dengan kadar hb saat menstruasi pada remaja. Metode yang digunakan dalam penelitian ini adalah analitik dengan rancangan case control. Teknik pengambilan sampel purposive sampling yaitu 24 remaja putri di SMA Negeri 1 Lebakwangi. Teknik pengumpulan data menggunakan lembar ceklist dan pemeriksaan haemoglobin dengan menggunakan haemoglobin blood test. Uji hipotesis dengan menggunakan uji chi square. Hasil penelitian didapatkan bahwa sebagian besar $(83,3 \%)$ remaja yang tidak mengkonsumsi $\mathrm{Fe}$ saat menstruasi mengalami anemia atau memiliki kadar haemoglobin rendah dan sebagian besar (75\%) remaja yang mengkonsumsi $\mathrm{Fe}$ saat menstruasi memiliki kadar haemoglobin normal atau tidak mengalami anemia. Hasil uji analitik didapatkan terdapat hubungan konsumsi tablet Fe dengan kadar $\mathrm{Hb}$ saat menstruasi pada remaja (p value 0,004). Kesimpulan konsumsi tablet Fe saat menstruasi dapat mempengaruhi peningkatan kadar haemoglobin secara signifikan.
\end{abstract}

Kata Kunci $\quad$ :Fe, anemia, remaja, menstruasi

\section{Pendahuluan}

Sumber

Daya Manusia yang

berkualitas merupakan faktor penentu utama dalam pembangunan kesehatan. Kesehatan memiliki efek jangka panjang sebagai bentuk investasi untuk Sumber Daya Manusia (Long term effect on Human Capital Investment) (Kementerian Kesehatan RI., 2015). Remaja merupakan Sumber Daya Manusia yang harus 
JOURNAL OF MIDWIFERY CARE :

VOL. 01 NO. 01, DESEMBER 2020

DOI : $\underline{10.34305 / j m c . v 1 i 1.181}$
Ciptaan disebarluaskan di bawah

Lisensi Creative Commons

Atribusi-NonKomersial-

BerbagiSerupa 4.0 Internasional. dilindungi karena potensinya yang sangat besar dalam upaya pembangunan kualitas bangsa, oleh karena itu suatu negara perlu mempersiapkan generasi muda secara fisik dan psikis, supaya mereka dapat menjadi generasi yang lebih baik dari yang sebelumnya. Anemia pada remaja menyebabkan pertumbuhan dan perkembangan tidak optimal dan menurunkan prestasi belajar karena rasa cepat lelah, kehilangan gairah, dan tidak dapat berkonsentrasi. Remaja membutuhkan cadangan zat besi sebagai calon ibu yang akan melahirkan generasi penerus bangsa, anemia akan menyebabkan tingginya risiko untuk melahirkan Berat Bayi Lahir Rendah (BBLR) yang mempunyai kualitas hidup yang tidak optimal. Melihat dampak anemia yang sangat besar dalam menurunkan kualitas Sumber Daya Manusia, maka sebaiknya penanggulangan anemia perlu dilakukan sejak dini sebelum remaja putri menjadi ibu hamil, agar kondisi fisik remaja putri tersebut telah siap menjadi ibu yang sehat(Puspitasari \& Sari, 2015).

Anemia didefinisikan sebagai suatu keadaan ketika kadar haemoglobin ( $\mathrm{Hb})$ di dalam darah lebih rendah daripada nilai keadaan normal. Nilai $\mathrm{Hb}$ ditentukan oleh umur, pada kelompok wanita dewasa nilai
$\mathrm{Hb}$ normal adalah 12 gr\%, dikatakan menderita anemia jika nilai $\mathrm{Hb}$ berada di bawah normal (Puspitasari \& Sari, 2015).

Menurut data hasil Riskesdas, (2013), prevalensi anemia di Indonesia yaitu $21,7 \%$ dengan penderita anemia berumur 514 tahun sebesar $26,4 \%$ dan $18,4 \%$ penderita berumur 15-24 tahun (Kementerian Kesehatan RI., 2014). Data Survei Kesehatan Rumah Tangga (SKRT), (2012) menyatakan bahwa prevalensi anemia pada balita sebesar 40,5\%, ibu hamil sebesar $50,5 \%$, ibu nifas sebesar $45,1 \%$, remaja putri usia 10-18 tahun sebesar $57,1 \%$ dan usia 19-45 tahun sebesar 39,5\%. Sedangkan untuk prevalensi anemia di Jawa Barat yaitu mencapai 41 \% (Dinkes Jabar: 2009). Kabupaten Kuningan terdapat $11 \%$ remaja putri yang mengalami anemia (Dinas Kesehatan Kuningan, 2016), SMA Negeri 1 Lebakwangi belum pernah dilakukan pemeriksaan kadar haemoglobin dan setelah dilakukan studi pendahuluan, remaja putri di SMA Negeri 1 Lebakwangi sebagian besar mempunyai kadar haemoglobin dibawah kadar normal. Tujuan penelitian ini adalah untuk mengetahui Hubungan konsumsi tablet $\mathrm{Fe}$ dengan kadar $\mathrm{Hb}$ saat Menstruasi pada remaja di SMA Negeri 1 Lebakwangi Kecamatan Lebakwangi Kabupaten 
JOURNAL OF MIDWIFERY CARE :

VOL. 01 NO. 01, DESEMBER 2020

DOI : $\underline{10.34305 / j m c . v 1 i 1.181}$

Kuningan Tahun 2017.

\section{Metode}

Jenis penelitian ini adalah penelitian analitik penelitian analitik adalah penelitian yang menekankan adanya hubungan antara satu variabel dengan variabel lainnya (Badriah, 2012). Rancangan penelitian pada penelitian ini adalah cases control, penelitian ini dilakukan pada tanggal $17 \mathrm{Juli}-25 \mathrm{Juli}$ 2017, sampel dalam penelitian ini yaitu remaja putri yang berusia 16-18 tahun di SMA Negeri 1 Lebakwangi berjumlah 24 orang yaitu 12 orang untuk kelompok kontrol dan 12 orang untuk kelompok kasus. Pengambilan sampel dalam penelitian ini
Ciptaan disebarluaskan di bawah

Lisensi Creative Commons

Atribusi-NonKomersial-

BerbagiSerupa 4.0 Internasional.

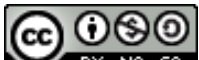

menggunakan teknik pengambilan non probabilitas yaitu sampel purposive dimana pengambilan sampel dipilih secara sengaja dengan mempertimbangkan tujuan yang ingin dicapai dari karakteristik yang ingin diteliti, variabel bebas dalam penelitian ini adalah tablet $\mathrm{Fe}$, konsumsi $\mathrm{Fe}$ dan tidak mengkonsumsi $\mathrm{Fe}$, sedangkan variabel terikat dalam penelitian ini adalah kadar hemoglobin. Instrumen pada penelitian ini yaitu pemeriksaan langsung kadar $\mathrm{Hb}$ dengan menggunakan hemoglobin blood test ( Hb Sahli).

Hasil

Analisis Univariat

Tabel 1. Konsumsi tablet Fe pada remaja di SMA Negeri 1 Lebakwangi Kuningan

\begin{tabular}{ccc}
\hline Tablet $\boldsymbol{F e}$ & Frekuensi & Persentase (\%) \\
\hline Tidak Konsumsi & 12 & 50 \\
Konsumsi & 12 & 50 \\
Jumlah & $\mathbf{2 4}$ & $\mathbf{1 0 0}$ \\
\hline
\end{tabular}

Sumber: Hasil Penelitian Tahun 2017

Berdasarkan hasil diatas dapat 12 responden (50\%).

diketahui bahwa dari 24 responden yang Distribusi frekuensi kadar $\mathrm{Hb}$ saat mengkonsumsi $\mathrm{Fe}$ saat menstruasi sebanyak menstruasi pada remaja di SMA Negeri 1 12 responden (50\%) dan yang tidak mengkonsumsi $\mathrm{Fe}$ saat menstruasi sebanyak Lebakwangi Kecamatan Lebakwangi Kabupaten Kuningan Tahun 2017 
Tabel 2. Kadar Hb saat Menstruasi pada remaja

\begin{tabular}{ccc}
\hline Kategori & Frekuensi & Persentase \% \\
\hline Anemia & 13 & 54,2 \\
Tidak Anemia & 11 & 45,8 \\
Jumlah & $\mathbf{2 4}$ & $\mathbf{1 0 0}$ \\
\hline
\end{tabular}

Sumber: Hasil Penelitian Tahun 2017

Berdasarkan tabel diatas dapat sebagian mengalami anemia sebanyak 13 diketahui bahwa dari 24 responden kadar $\mathrm{Hb}$ responden $(54,2 \%)$.

saat menstruasi pada remaja hampir

Analisis Bivariat

Tabel 3. Hubungan konsumsi tablet Fe dengan kadar Hb saat menstruasi pada remaja

\begin{tabular}{|c|c|c|c|c|c|c|c|}
\hline \multirow{3}{*}{ Tablet $F e$} & \multicolumn{4}{|c|}{ Kadar Hb } & \multicolumn{2}{|c|}{ Total } & \multirow[t]{3}{*}{ PValue } \\
\hline & \multicolumn{2}{|c|}{ Anemia } & \multicolumn{2}{|c|}{ Tidak Anemia } & \multirow[b]{2}{*}{$\mathbf{F}$} & \multirow[b]{2}{*}{$\%$} & \\
\hline & $\mathbf{F}$ & $\%$ & $\mathbf{F}$ & $\%$ & & & \\
\hline Tidak Konsumsi & 10 & 83,3 & 2 & 16,7 & 12 & 100 & 0,004 \\
\hline Konsumsi & 3 & 25,0 & 9 & 75,0 & 12 & 100 & \\
\hline
\end{tabular}

Sumber : Hasil Penelitian Tahun 2017

Berdasarkan tabel diatas dapat dijelaskan bahwa dari 12 responden yang tidak mengkonsumsi $\mathrm{Fe}$ saat menstruasi sebagian besar mengalami anemia $(83,3 \%)$ sedangkan responden yang mengkonsumsi $\mathrm{Fe}$ sebagian besar tidak mengalami anemia $(75,0 \%)$. Hasil uji chi-square di dapat nilai p-value yaitu $0,004<\alpha=0,05$ yang artinya terdapat hubungan antara konsumsi tablet $\mathrm{Fe}$ dengan kadar $\mathrm{Hb}$ saat menstruasi.

\section{Pembahasan}

\section{Analisis Univariat}

defisiensi besi adalah kurangnya asupan salah satu mikronutrien penting yaitu zat besi. Anemia defisiensi besi masih merupakan penyakit dengan prevalensi tinggi. Sehingga pemenuhan kebutuhan zat besi ini diperlukan untuk mencegah atau menanggulangi anemia, hal ini sesuai dengan teori yang disampaikan oleh Almatsier (2010) dalam Kusmawati \& Rokhanawati, (2016), yang mengatakan bahwa pemberian tablet tambah darah merupakan salah satu penanganan yang 
JOURNAL OF MIDWIFERY CARE :

VOL. 01 NO. 01, DESEMBER 2020

DOI : $\underline{10.34305 / j m c . v 1 i 1.181}$
Ciptaan disebarluaskan di bawah

Lisensi Creative Commons

Atribusi-NonKomersial-

BerbagiSerupa 4.0 Internasional. dilakukan untuk menanggulangi anemia pada remaja.

Remaja putri membutuhkan zat besi paling banyak yang digunakan untuk mengganti besi yang terbuang bersama darah haid di samping keperluan untuk menopang pertumbuhan serta kematangan seksual. Hal ini sesuai dengan penelitian yang dilakukan oleh Kusmawati \& Rokhanawati, (2016). yang mengatakan bahwa berdasarkan kebiasaan minum tablet $F e$ saat menstruasi dengan kejadian anemia didapatkan hasil sebanyak 30 siswi yang tidak terbiasa meminum tablet $\mathrm{Fe}$ saat menstruasi, 18 siswi diantaranya mengalami anemia dan yang tidak mengalami anemia sebanyak 12 siswi. Hasil penelitian ini didukung oleh teori Almatsier (2011) dalam Kusmawati \& Rokhanawati, (2016), yang mengatakan bahwa menambah pemasukan zat besi dalam tubuh dengan meminum tablet $\mathrm{Fe}$ dapat mencegah terjadinya anemia. Pemberian suplementasi besi saat menstruasi memberikan pengaruh peningkatan kadar haemoglobin secara signifikan. Pemberian tablet $F e$ pasca menstruasi pada remaja putri merupakan sebuah paradigma baru dalam pencegahan anemia remaja, karena itu terapi zat besi merupakan terapi pilihan pertama oleh karena efektif, mudah dan aman digunakan (Arisman, 2011 dalam Martini, 2016).

Berdasarkan hasil penelitian yang didapat bahwa dari 24 responden kadar $\mathrm{Hb}$ saat menstruasi pada remaja sebagian besar mengalami anemia sebanyak 13 responden (54,2 \%). Menurut Slams, dkk (2010) dalam Aini, (2014), mengemukakan bahwa wanita atau remaja putri yang sedang mengalami menstruasi merupakan populasi yang harus diperhatikan. Remaja putri yang mengalami menstruasi memiliki kecenderungan defisiensi zat besi sebanyak 5\% sampai dengan 10\%, sehingga remaja putri yang mengalami menstruasi rentan terhadap terjadinya penurunan kadar $\mathrm{Hb}$ atau anemia. Selama menstruasi, remaja putri mengalami pengeluaran atau kehilangan darah yang banyak.

\section{Analisis Bivariat}

Berdasarkan tabel 5.3 dilihat dari hasil uji statistik diperoleh nilai $\mathrm{p}=0,004<$ $\alpha=0,05$. Hasil penelitian ini membuktikan bahwa pemberian suplementasi besi saat menstruasi berhubungan dengan peningkatan kadar haemoglobin secara signifikan. Peningkatan kadar haemoglobin dalam darah juga dipengaruhi oleh beberapa faktor yang dapat mempermudah absorpsi (penyerapan) zat besi. Berikut merupakan 
JOURNAL OF MIDWIFERY CARE :

VOL. 01 NO. 01, DESEMBER 2020

DOI : $\underline{10.34305 / j m c . v 1 i 1.181}$

faktor yang dapat meningkatkan penyerapan zat besi yaitu dengan mengkonsumsi tablet penambah darah bersama dengan buahbuahan sumber vitamin C seperti jeruk, jambu biji, mangga pepaya dan buah-buahan lainnya (Martini, 2016).

Remaja putri memiliki risiko sepuluh kali lebih besar menderita anemia dibandingkan remaja putra. Hal ini karena remaja putri mengalami menstruasi setiap bulannya. Selain itu, ketidakseimbangan asupan zat gizi juga menjadi penyebab anemia pada remaja. Anemia yang dialami remaja putri ini dapat menimbulkan berbagai dampak antara lain menurunkan daya tahan tubuh, menurunnya aktivitas dan prestasi belajar serta kebugarannya juga akan menurun, sehingga menghambat prestasi olahraga, produktivitas dan pertumbuhan terutama pertumbuhan pada tinggi badannya (Arisman, 2009 dalam Martini, 2016). Oleh karena itu diperlukan pencegahan anemia yang salah satunya adalah dengan menambah pemasukan zat besi kedalam tubuh dengan meminum tablet $F e$ saat sedang menstruasi (Almatsier, 2011 dalam Martini, 2016).

Penelitian ini sejalan dengan penelitian yang dilakukan oleh Kusmawati \& Rokhanawati, (2016) yang memaparkan bahwa berdasarkan hasil analisis statistik chi square didapatkan hasil terdapat hubungan antara kebiasaan minum tablet $F e$ saat menstruasi dengan kejadian anemia yang dibuktikan dengan $\mathrm{p}$-value $=0,008(\mathrm{p}<$ $0,05)$. Adanya hubungan dalam penelitian ini didukung oleh beberapa teori diantaranya Aryandhito (2009) dalam Kusmawati \& Rokhanawati, (2016), yang mengatakan bahwa kehilangan darah saat menstruasi berarti mengeluarkan zat besi yang ada dalam darah dan dapat menyebabkan terjadinya anemia. Dalam penelitian terdapat beberapa faktor yang dapat mempengaruhi peningkatan kadar haemoglobin diantaranya siswi dapat meminum tablet $\mathrm{Fe}$ secara teratur setiap harinya saat mereka sedang menstruasi dan mereka sudah tahu mengenai cara mengkonsumsi tablet $\mathrm{Fe}$ yang benar yaitu selain menggunakan air putih bisa juga dengan menggunakan air jeruk ataupun makanan yang mengandung vitamin $\mathrm{C}$ dan meminumnya pada malam hari menjelang tidur agar terhindar dari rasa mual.

Hasil penelitian ini didukung oleh Puspitasari \& Sari, (2015), yang mengemukakan bahwa terdapat perbedaan antara kelompok perlakuan dan kelompok kontrol dengan nilai $\mathrm{p}=0,0001$ atau $(\mathrm{p}<0,05)$, ini berarti bahwa dengan pemberian tablet 
JOURNAL OF MIDWIFERY CARE :

VOL. 01 NO. 01, DESEMBER 2020

DOI : $\underline{10.34305 / j m c . v 1 i 1.181}$
Ciptaan disebarluaskan di bawah

Lisensi Creative Commons

Atribusi-NonKomersial-

BerbagiSerupa 4.0 Internasional. tambah darah selama menstruasi dapat meningkatkan kadar haemoglobin darah pada remaja. Pemberian suplementasi besi seminggu sekali dengan menambahkan saat menstruasi dapat meningkatkan kadar haemoglobin. Penelitian ini juga sejalan dengan penelitian yang telah dilakukan oleh Nurhudariani \& Purwati, (2017) bahwa pemberian tablet $\mathrm{Fe}$ berhubungan dengan peningkatan kadar $\mathrm{Hb}$ saat menstruasi dibuktikan dengan hasil penelitian menggunakan pengujian Wilcoxon ranks test diperoleh $\mathrm{p}$ value sebesar 0,000 $(\mathrm{p}<0,05)$. Pemberian suplementasi besi menguntungkan karena dapat memperbaiki status hemoglobin dalam waktu yang relatif singkat. Sampai sekarang cara ini masih merupakan satu-satunya cara yang cocok dilakukan pada ibu hamil dan kelompok yang berisiko tinggi lainnya, seperti anak balita, anak sekolah, dan pekerja. Di Indonesia, tablet zat besi yang umum digunakan dalam suplementasi zat besi ini adalah Ferrosus sulfat, senyawa ini tergolong murah dan dapat diabsorpsi sampai 20\%. Dosis yang digunakan beragam, tergantung pada status besi orang yang mengkonsumsinya. Biasanya ibu hamil yang rawan anemia diberi dosis yang lebih tinggi dibandingkan dengan wanita biasa.
Kendala utama dalam suplementasi zat besi ini adalah efek samping yang dihasilkan dan kesulitan mematuhi meminum tablet $\mathrm{Fe}$ karena kurangnya kesadaran akan pentingnya masalah anemia gizi besi. Efek samping dari pemberian zat besi ini adalah saluran pencernaan, seperti mual, muntah, konstipasi, dan diare. Semakin tinggi dosis yang diberikan, maka kemungkinan efek samping akan semakin besar. Zat besi yang diminum dalam keadaan perut terisi akan mengurangi efek samping yang ditimbulkan, tetapi hal ini dapat menurunkan tingkat penyerapannya (Emma S. Wirakusumah, 2009 dalam Nurhudariani \& Purwati, 2017).

\section{Kesimpulan}

Remaja yang mengkonsumsi $\mathrm{Fe}$ saat menstruasi sebanyak 12 responden (50\%) dan yang tidak mengkonsumsi $F e$ saat menstruasi sebanyak 12 responden (50\%), remaja yang sedang menstruasi sebanyak 24 responden hampir sebagian mengalami anemia sebanyak $54,2 \%$, terdapat hubungan antara konsumsi tablet $\mathrm{Fe}$ dengan kadar $\mathrm{Hb}$ saat menstruasi pada remaja.

\section{Saran}

Para remaja putri diharapkan dapat meningkatkan pengetahuan mengenai 
JOURNAL OF MIDWIFERY CARE :

VOL. 01 NO. 01, DESEMBER 2020

DOI : $\underline{10.34305 / j m c . v 1 i 1.181}$
Ciptaan disebarluaskan di bawah

Lisensi Creative Commons

Atribusi-NonKomersial-

BerbagiSerupa 4.0 Internasional pentingnya konsumsi $\mathrm{Fe}$ pada saat menstruasi dan pola asupan gizi untuk mencegah terjadinya anemia.

\section{Daftar Pustaka}

Aini, E. . (2014). Hubungan Sikus Menstruasi Dan Periode Menstruasi Dengan Kejadian Anemia Pada Remaja Perempuan Di Madrasah Aliyyah Ma'arif Kadugede Tahun 2015. Karya Tulis Ilmiah. Sekolah Tinggi Ilmu Kesehatan Kuningan.

Badriah, D. L. (2012). Metodologi Penelitian Ilmu-Ilmu Kesehatan. Bandung: Multazam.

Dinas Kesehatan Jawa Barat. (2009). Angka Kejadian Anemia Remaja. http://www.diskes.jabarprov.go.id/.,

Dinas Kesehatan Kuningan. (2016). Laporan Akhir Tahun Anemia Pada Remaja Putri Kuningan:

Kemenkes, R. I. (2013). Riset Kesehatan Dasar Tahun 2013. Badan Penelitian Dan Pengembangan Kesehatan Kemenkes Ri, Jakarta: Kemenkes Ri.

Kementerian Kesehatan RI. (2014). Riset Kesehatan Dasar Tahun 2013. Jakarta: Kementrian Kesehatan Republik Indonesia.

Kementerian Kesehatan Ri. (2015). Status Gizi Pengaruhi Kualitas Bangsa. Jakarta: Departemen Kesehatan
Republik Indonesia. Http://Www.Depkes.Go.Id/Article/Pri nt/15021300004/Status-Gizi-

Pengaruhi-Kualitas-Bangsa.Html.

Kusmawati, I. I., \& Rokhanawati, D. (2016). Kebiasaan Minum Tablet Fe Saat Menstruasi Dengan Kejadian Anemia Pada Siswi Kelas Xi Di Sma Muhammadiyah 7 Yogyakarta Tahun 2016. Universitas' Aisyiyah Yogyakarta.

Martini, M. (2016). Faktor-Faktor Yang Berhubungan Dengan Kejadian Anemia Pada Remaja Putri Di Man 1 Metro. Jurnal Kesehatan Metro Sai Wawai, 8(1), 1-7.

Nurhudariani, R., \& Purwati, S. (2017). Pengaruh Pemberian Suplemen Besi Saat Menstruasi Terhadap Kadar $\mathrm{Hb}$ Mahasiswi Tingkat I Diii Keperawatan Stikes Karya Husada Semarang. Jurnal Smart Kebidanan, 3(2), 85-92.

Puspitasari, D., \& Sari, A. A. (2015). Pengaruh Pemberian Suplemen Besi Saat Menstruasi Terhadap Peningkatan Kadar Haemoglobin Pada Remaja Di Smun I Bantul Yogyakarta. Media Ilmu Kesehatan, 4(3), 156-161.

Survei Kesehatan Rumah Tangga (Skrt). (2012). Hubungan Antara Asupan Protein Dengan Kejadian Anemia Pada Remaja Putri. Http://Eprinte.Ums.Ac.Id/39695/3/Ba b I Endar.Pdf., 